\title{
UDC 004.2
}

\section{MATHEMATICAL MODEL OF CORROSION INSIDE METAL WATER PIPES}

Nguyen H.C.

Ph.D.

Nguyen N.T.

Master

Ho Chi Minh University of Natural Resources and Environment, Ho Chi Minh, Le Van Sy 236B, 72100

\begin{abstract}
In water supply systems, one of the most important factors is corrosion of pipelines from steel and cast-iron pipes, an increase in pressure losses, which reduces water flow and increases energy consumption. Excessive corrosion intensity is determined by roughness coefficient $C$, but determining roughness coefficient of old metal pipes is difficult. The results of the research are the obtained formulas, based on numerous experimental studies of various authors, allow one to theoretically determine the dependence of the roughness coefficient $C$ on the age of operation and the composition of natural waters of cast-iron pipes, steel pipes and pipes with internal cement coatings. Analysis of calculation results according to the new formula indicates that the decreasing amplitudes of the roughness coefficient $C$ slow down after 20,30, 40, 50 years and do not decrease to zero.
\end{abstract}

Key words: corrosion, roughness coefficient, absolute roughness, characteristics of natural waters, hydraulic friction

\section{Research on the roughness of the pipe's inner surface}

An operation indicator of water supply networks is the head loss due to friction in the pipes (h) and the minimum roughness of the pipe's inner surface (e). For hydraulic calculations of water pipelines for determining pressure losses, the wellknown formulas Hazen-Williams (formula 1) and Darcy - Weisbach:

$$
h=\lambda \frac{L}{D_{p}} \frac{W^{2}}{2 g}
$$

$\mathrm{D}_{\mathrm{p}}$ - is the pipe's diameter; $\mathrm{W}-$ is the water velocity; $\mathrm{L}-$ is the length of the pipe section; $\lambda-$ is the coefficient of hydraulic friction.

The widely used approximation of the coefficient $(\lambda)$ by A. D. Altshul [1]:

$$
\lambda=0,11\left(\frac{e}{D_{p}}+\frac{68}{\mathrm{Re}}\right)^{0,25}
$$

which "is experimentally confirmed for the coefficient of hydraulic friction. When the $\operatorname{Re}\left(e / D_{p}\right)>500$ for rough pipes, the formula of A D Altshul is in good agreement with the Shifrinson's formula, for smooth pipes $\operatorname{Re}\left(e / D_{p}\right)<10$ coincides with the Blasius's formula" [2]. The roughness height values (e) in the known formulas correspond to pipes with large corrosion or hydraulically smooth pipes. When determining the roughness coefficient, the duration of pipe operation is not taken into account.

Professor F A Shevelev, on the basis of the formula of A D Altshul, determined the dependence of the coefficient $\lambda$ on the operating time of the pipelines.

At the suggestion of M Ya Panov, A S Levadny, V I Shcherbakov, V G Stogney, based on the studies of F A Shevelev, to use the following dependencies to 
take into account the duration of pipe operation for determining the coefficient of hydraulic friction $\lambda[1]$ :

$$
\lambda_{T}=\lambda_{0}+\frac{0,8 \varepsilon[1-\exp (-0,1 T)]}{1-\exp (-4 D)},
$$

$\lambda_{0}=\frac{0,01559}{D^{0,226}}\left(1+\frac{0,684}{W}\right)^{0,226} ; \mathrm{D}-$ the calculated pipe diameter, $\mathrm{T}-$ the operating time, years; $\mathrm{W}$ - the average velocity of the water flow in the pipe, $\mathrm{m} / \mathrm{s} ; \lambda 0$ is the coefficient of hydraulic friction for new steel pipes; $\varepsilon$ - the corrosivity of water, the ratio of corrosion products per unit surface $\left(\mathrm{mg} / \mathrm{cm}^{2}\right)$.

Researches on the roughness of the pipe's inner surface made of various materials were classified, the roughness coefficients were determined depending on duration of operation of steel and cast-iron pipes based on numerous experimental data from various authors, This data is not included in this paper because of the volume is large [3].

\section{Formulas are proposed to determine roughness coefficient $\mathbf{C}$}

The paper also considers the characteristic of natural waters, reducing the pipepipe flow depending on the duration of work and the formation of deposit corrosion. At the same time, the roughness of the pipe increases in the steel and cast iron pipes. Deposits on pipe's inner surface and corrosion reduce the diameter of the pipe, leading to an increase in head loss. These processes are not affected in plastic, asbestos-cement and glass pipes. According to the research of A G Kamerstein, all natural waters are divided into five groups, depending on the physical, chemical and biological factors affecting the change in the roughness of the pipe walls and the decrease in pipeline capacity [4].

For the first time, taking into account the operating time of the pipes, based on formula 3 , the following formulas are proposed to determine roughness coefficient $\mathrm{C}$ : for cast-iron pipes:

$$
C=C_{0}-\left(\frac{19^{*} \mathrm{e}[1-\exp (-\partial T)]}{1-\exp (-4 D)}\right)^{2}
$$

for steel pipes:

$$
C=C_{0}-\left(\frac{114 * \mathrm{e}[1-\exp (-\partial T)]}{1-\exp (-4 D)}\right)^{2}
$$

for pipes with internal cement coatings:

$$
C=C_{0}-\left(\frac{15^{*} \mathrm{e}[1-\exp (-\partial T)]}{1-\exp (-4 D)}\right)^{2}
$$

$\partial$ - the annual increase in absolute roughness, $\mathrm{mm}$ per year; $\mathrm{C}_{0}$ - the roughness coefficient of new pipes.

According to the research of A.G. Kamenshtein taking into account the annual growth of absolute roughness for different groups, the roughness coefficient $\mathrm{C}$ is determined for pipes with a diameter of $250 \mathrm{~mm}$ and $400 \mathrm{~mm}$ (table 1). The calculation results according to formulas $4,5,6$ for cast iron and steel pipes, pipes with internal cement coatings are shown in Table 2, 3, 4 (Figures 1, 2, 3). 
Table 1

\section{Characteristics of natural waters increase in absolute roughness in pipes}

\begin{tabular}{|c|c|c|c|}
\hline Group & $\begin{array}{c}\text { Corrosive } \\
\text { effect }\end{array}$ & Natural water characterization & $\begin{array}{l}\text { Annual increase in } \\
\text { absolute roughness, } \\
\text { mm per year }(\partial)\end{array}$ \\
\hline Group 1 & low & $\begin{array}{l}\text { Slightly mineralized non-corrosive waters with a } \\
\text { stability index from }-0.2 \text { to }+0.2 \text {; water with } \\
\text { little organic matter and dissolved iron. }\end{array}$ & $\begin{array}{l}0.005-0.05 \text { (on } \\
\text { average } 0.025)\end{array}$ \\
\hline Group 2 & Moderate & $\begin{array}{c}\text { Low-mineralized non-corrosive water with a } \\
\text { stability index up to - } 1.0 \text {; water containing } \\
\text { organic matter and dissolved iron in an amount } \\
\text { less than } 3 \mathrm{~g} / \mathrm{m}^{3} \text {. }\end{array}$ & $\begin{array}{l}0.055-0.18(\text { on } \\
\text { average } 0.07)\end{array}$ \\
\hline Group 3 & Significant & $\begin{array}{l}\text { Extremely corrosive water with a stability index } \\
\text { from - } 1.0 \text { to } 2.5 \text {, but with a low content of } \\
\text { chlorides and sulfates (less than } 100-150 \mathrm{~g} / \mathrm{m}^{3} \text { ); } \\
\text { water with more iron content } 3 \mathrm{~g} / \mathrm{m}^{3} \text {. }\end{array}$ & $\begin{array}{c}0.18-0.4 \text { (on average } \\
0.20)\end{array}$ \\
\hline Group 4 & Strong & $\begin{array}{c}\text { Corrosive waters with a negative stability index, } \\
\text { but with a high content of sulfates and chlorides } \\
\left(\text { more than } 500-700 \mathrm{~g} / \mathrm{m}^{3}\right) \text {; high organic matter } \\
\text { untreated water }\end{array}$ & $\begin{array}{c}0.4-0.6 \text { (on average } \\
0.51 \text { ) }\end{array}$ \\
\hline Group 5 & $\begin{array}{l}\text { Very } \\
\text { strong }\end{array}$ & $\begin{array}{l}\text { Waters characterized by significant carbonate } \\
\text { and low constant density with a stability index of } \\
\text { more than } 0.8 \text {; highly mineralized and corrosive } \\
\text { waters with a dense sediment of more than } 2000 \\
\mathrm{~g} / \mathrm{m}^{3} .\end{array}$ & $0.6-3.0$ \\
\hline
\end{tabular}

Table 2

The dependence of the roughness coefficient $C$ of cast-iron pipes on the diameter, age of operation and characteristics of natural waters

\begin{tabular}{|c|c|c|c|c|c|c|c|c|c|c|}
\hline \multirow{2}{*}{ 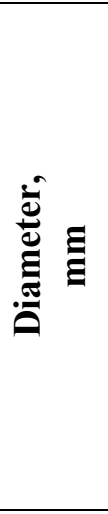 } & \multirow{2}{*}{ 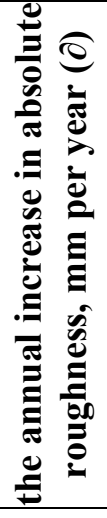 } & \multirow{2}{*}{ 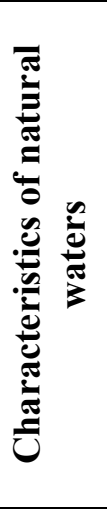 } & \multirow{2}{*}{ 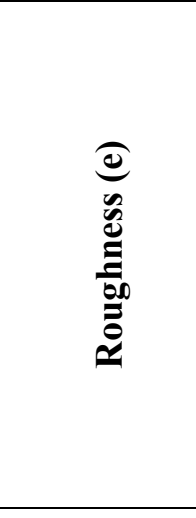 } & \multicolumn{7}{|c|}{$\begin{array}{l}\text { Roughness coefficient } \mathrm{C} \text { of new and used pipes (Hazen- } \\
\text { Williams) }\end{array}$} \\
\hline & & & & New & $\begin{array}{c}5 \\
\mathbf{5} \\
\text { years }\end{array}$ & $\begin{array}{c}10 \\
\text { years }\end{array}$ & $\begin{array}{c}20 \\
\text { years }\end{array}$ & $\begin{array}{c}30 \\
\text { years }\end{array}$ & $\begin{array}{c}40 \\
\text { years }\end{array}$ & $\begin{array}{c}50 \\
\text { years }\end{array}$ \\
\hline \multirow{3}{*}{250} & \multirow{3}{*}{$\stackrel{n}{\mathscr{\theta}}$} & \multirow{3}{*}{$\vec{\Xi}$} & $\mathrm{e}=0,3 \mathrm{~mm}$ & & 127,9 & 122,9 & 109,4 & 95,6 & 83,8 & 74,5 \\
\hline & & & $\mathrm{e}=0,28 \mathrm{~mm}$ & 130 & 128,2 & $\begin{array}{c}1 \\
23,8\end{array}$ & 112,0 & 100,1 & 89,8 & 81,6 \\
\hline & & & $\mathrm{e}=0,26 \mathrm{~mm}$ & & 128,4 & 124,7 & 114,5 & 104,2 & 95,3 & 88,3 \\
\hline
\end{tabular}




\begin{tabular}{|c|c|c|c|c|c|c|c|c|c|}
\hline \multirow{3}{*}{400} & & & $\mathrm{e}=0,3 \mathrm{~mm}$ & 128,7 & 125,6 & 117,1 & 108,4 & 101,0 & 95,2 \\
\hline & & & $\mathrm{e}=0,28 \mathrm{~mm}$ & 128,9 & 126,1 & 118,7 & 111,2 & 104,8 & 99,7 \\
\hline & & & $\mathrm{e}=0,26 \mathrm{~mm}$ & 129,0 & 126,7 & 120,3 & 113,8 & 108,3 & 103,8 \\
\hline \multirow{3}{*}{250} & \multirow{6}{*}{$\frac{\mathscr{O}}{\hat{\sigma}}$} & & $\mathrm{e}=0,3 \mathrm{~mm}$ & 118,4 & 99,4 & 71,2 & 57,8 & 52,3 & 50,1 \\
\hline & & & $\mathrm{e}=0,28 \mathrm{~mm}$ & 119,9 & 103,4 & 78,8 & 67,1 & 62,3 & 60,4 \\
\hline & & 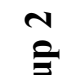 & $\mathrm{e}=0,26 \mathrm{~mm}$ & 121,3 & 107,0 & 85,8 & 75,8 & 71,6 & 70,0 \\
\hline \multirow{3}{*}{400} & & 光 & $\mathrm{e}=0,3 \mathrm{~mm}$ & 122,7 & 110,8 & 93,1 & 84,7 & 81,2 & 79,9 \\
\hline & & & $\mathrm{e}=0,28 \mathrm{~mm}$ & 123,6 & 113,3 & 97,9 & 90,6 & 87,5 & 86,3 \\
\hline & & & $\mathrm{e}=0,26 \mathrm{~mm}$ & 124,5 & 115,6 & 102,3 & 96,0 & 93,4 & 92,3 \\
\hline \multirow{3}{*}{250} & \multirow{6}{*}{$\overrightarrow{\tilde{g}}$} & & $\mathrm{e}=0,3 \mathrm{~mm}$ & 79,5 & 55,8 & 49,0 & 48,7 & 48,5 & 48,3 \\
\hline & & & $\mathrm{e}=0,28 \mathrm{~mm}$ & 86,0 & 65,4 & 59,5 & 59,2 & 59,0 & 58,8 \\
\hline & & $\stackrel{m}{\xi}$ & $\mathrm{e}=0,26 \mathrm{~mm}$ & 92,1 & 74,3 & 69,2 & 68,9 & 68,7 & 68,5 \\
\hline \multirow{3}{*}{400} & & Uँ & $\mathrm{e}=0,3 \mathrm{~mm}$ & 98,3 & 83,5 & 79,2 & 79,0 & 78,8 & 78,6 \\
\hline & & & $\mathrm{e}=0,28 \mathrm{~mm}$ & 102,4 & 89,5 & 85,7 & 85,6 & 85,4 & 85,2 \\
\hline & & & $\mathrm{e}=0,26 \mathrm{~mm}$ & 106,2 & 95,1 & 91,8 & 91,7 & 91,6 & 91,5 \\
\hline
\end{tabular}

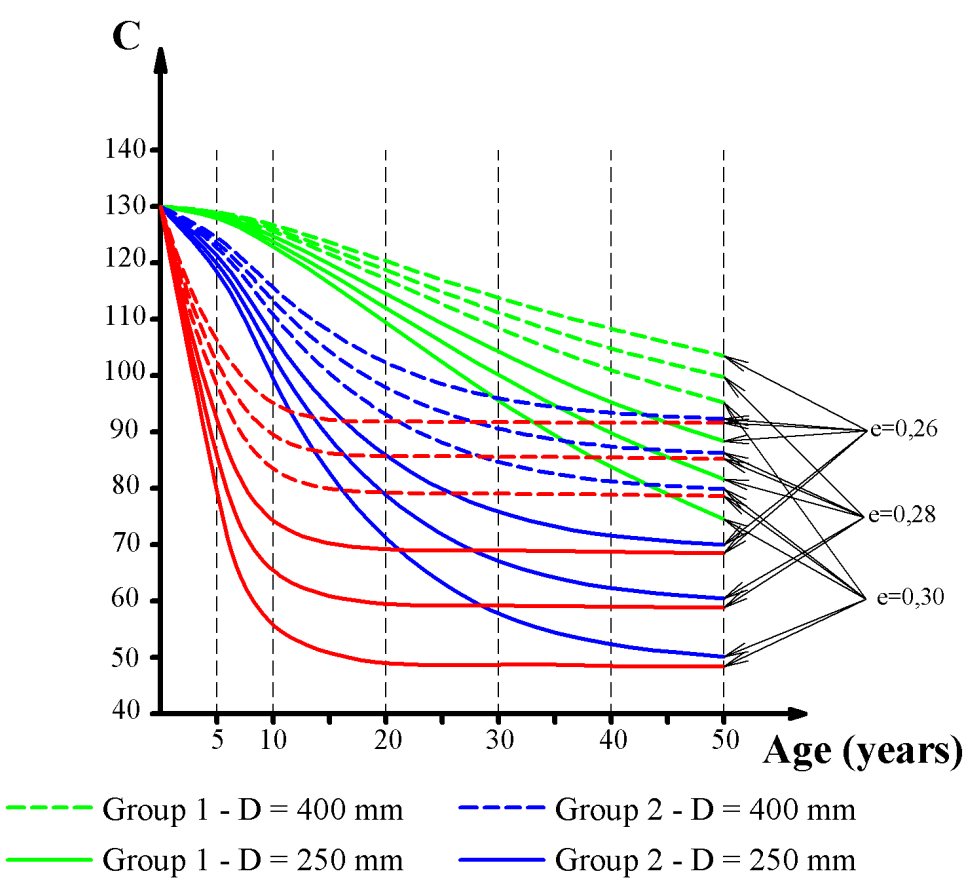

---- Group 3 - D = $400 \mathrm{~mm}$

Group 3 - D = $250 \mathrm{~mm}$

Fig. 1. Change in the roughness coefficient $C$ of cast-iron pipes from the age of operation and characteristics of natural waters. 
Table 3

The dependence of the roughness coefficient $C$ of steel pipes on the diameter, age of operation and characteristics of natural waters.

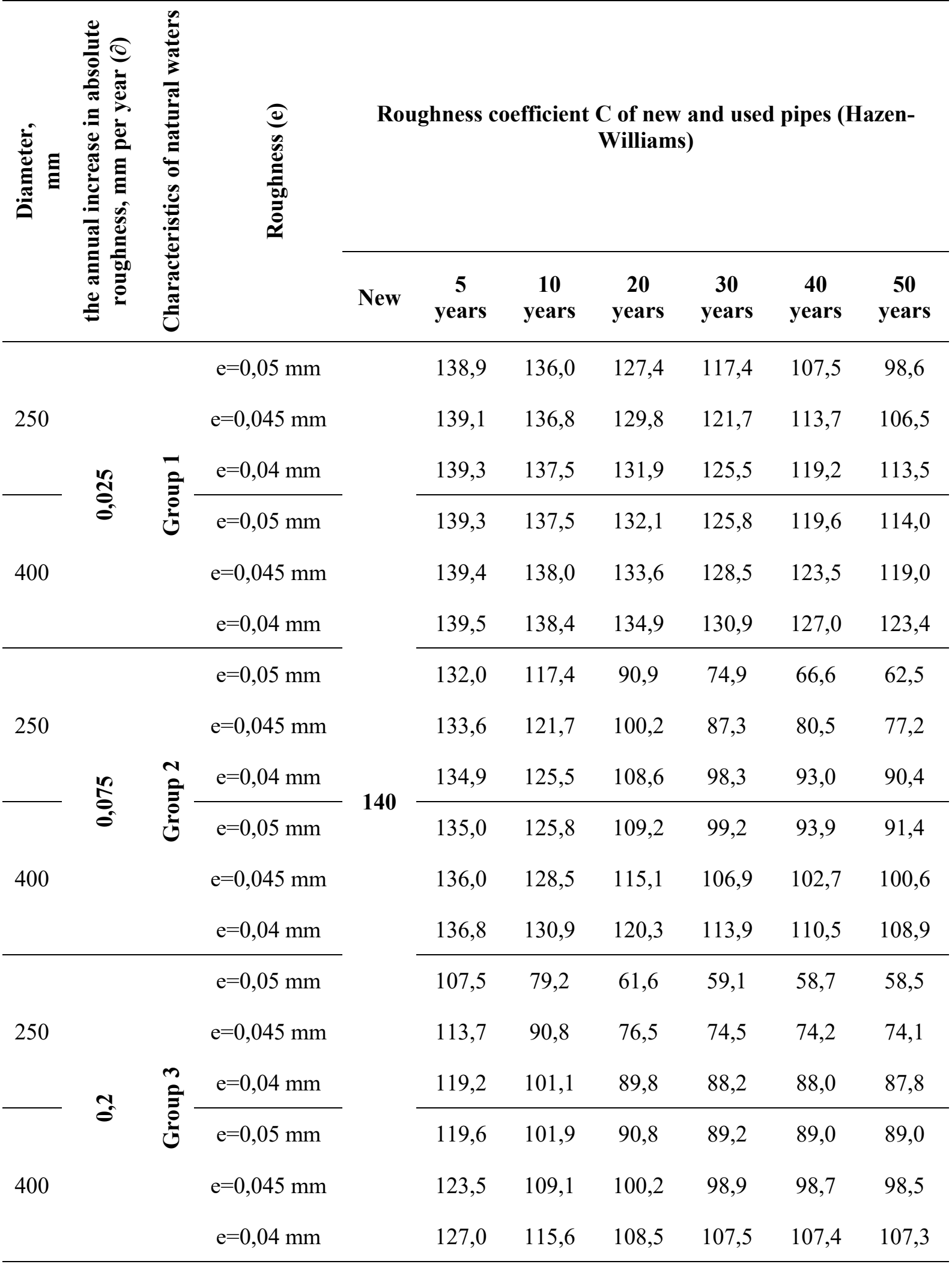




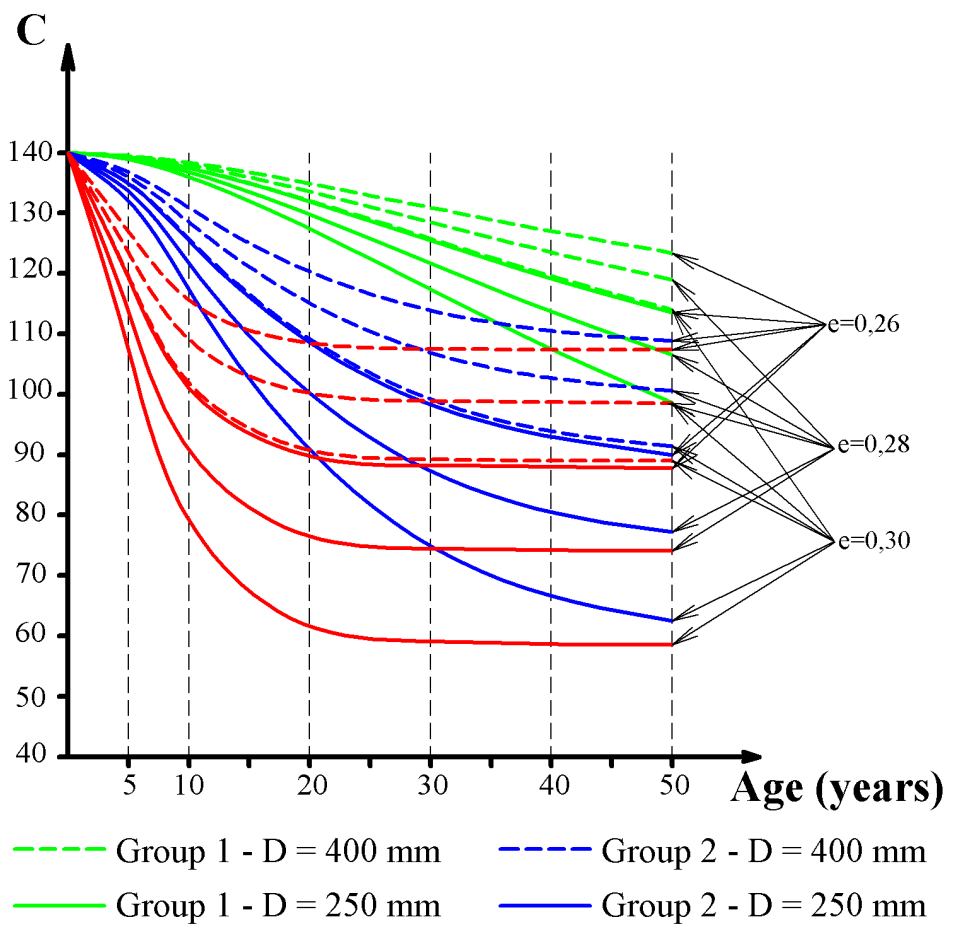

---- Group 3 - D = $400 \mathrm{~mm}$

Group 3 - D = $250 \mathrm{~mm}$

Fig. 2. Change in the roughness coefficient $C$ of steel pipes from the age of their operation and the characteristics of natural waters.

Table 4

The dependence of the roughness coefficient $C$ of pipes with internal cement coatings on the diameter, age of operation and characteristics of natural waters.

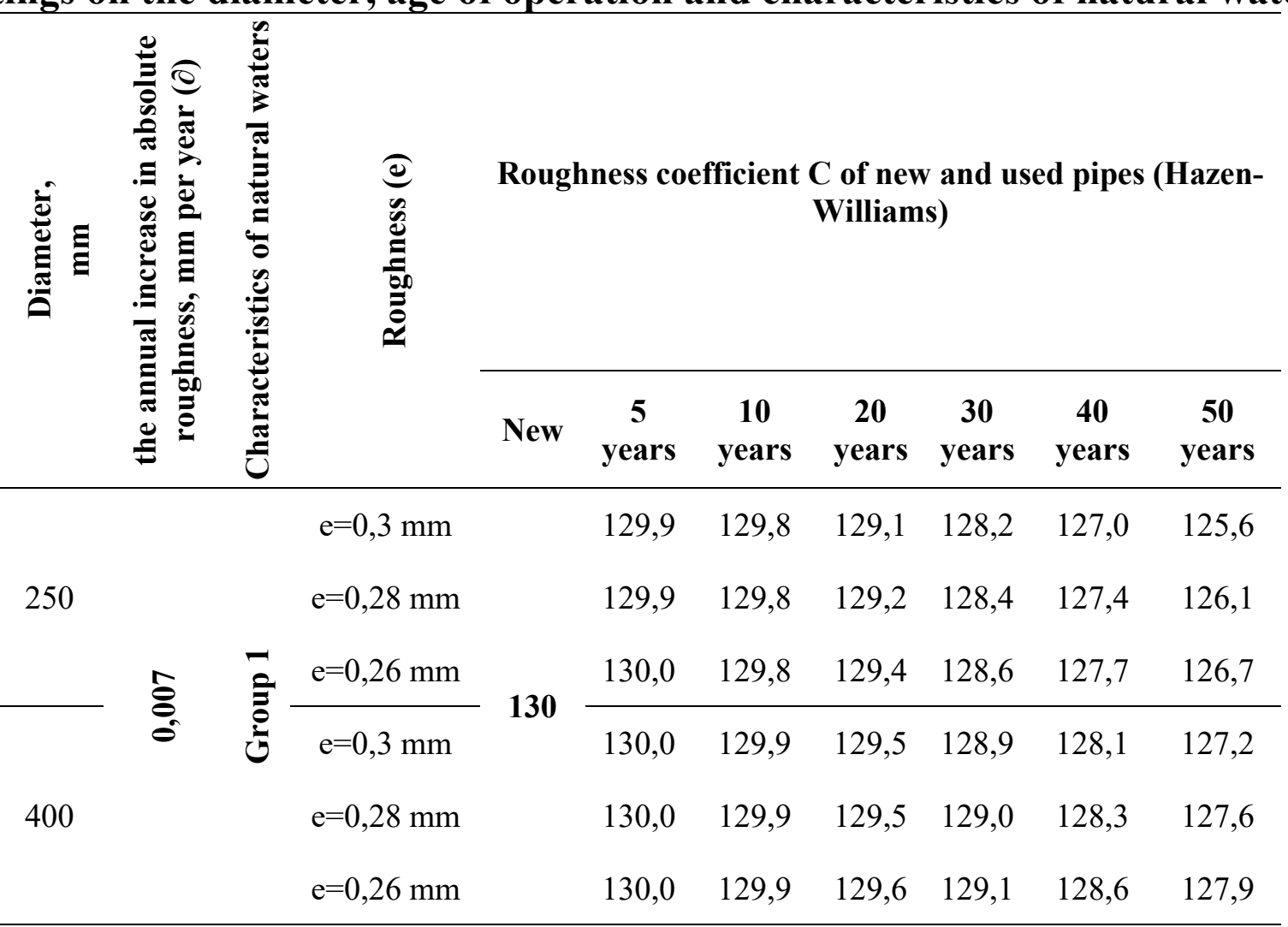




\begin{tabular}{|c|c|c|c|c|c|c|c|c|c|}
\hline \multirow{3}{*}{250} & \multirow{6}{*}{$\mathscr{\theta}_{0}$} & \multirow{6}{*}{ 䏠 } & $\mathrm{e}=0,3 \mathrm{~mm}$ & 127,5 & 122,2 & 109,7 & 99,4 & 92,1 & 87,3 \\
\hline & & & $\mathrm{e}=0,28 \mathrm{~mm}$ & 127,8 & 123,2 & 112,4 & 103,4 & 97,0 & 92,8 \\
\hline & & & $\mathrm{e}=0,26 \mathrm{~mm}$ & 128,1 & 124,1 & 114,8 & 107,0 & 101,5 & 97,9 \\
\hline \multirow{3}{*}{400} & & & $\mathrm{e}=0,3 \mathrm{~mm}$ & 128,4 & 125,1 & 117,3 & 110,8 & 106,2 & 103,2 \\
\hline & & & $\mathrm{e}=0,28 \mathrm{~mm}$ & 128,6 & 125,7 & 118,9 & 113,3 & 109,3 & 106,7 \\
\hline & & & $\mathrm{e}=0,26 \mathrm{~mm}$ & 128,8 & 126,3 & 120,5 & 115,6 & 112,1 & 109,9 \\
\hline \multirow{3}{*}{250} & \multirow{6}{*}{$\bar{\theta}$} & & $\mathrm{e}=0,3 \mathrm{~mm}$ & 122,2 & 109,7 & 92,1 & 84,2 & 81,2 & 80,0 \\
\hline & & & $\mathrm{e}=0,28 \mathrm{~mm}$ & 123,2 & 112,4 & 97,0 & 90,1 & 87,5 & 86,4 \\
\hline & & $\stackrel{m}{=}$ & $\mathrm{e}=0,26 \mathrm{~mm}$ & 124,1 & 114,8 & 101,5 & 95,6 & 93,3 & 92,4 \\
\hline \multirow{3}{*}{400} & & 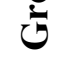 & $\mathrm{e}=0,3 \mathrm{~mm}$ & 125,1 & 117,3 & 106,2 & 101,3 & 99,4 & 98,6 \\
\hline & & & $\mathrm{e}=0,28 \mathrm{~mm}$ & 125,7 & 118,9 & 109,3 & 105,0 & 103,3 & 102,7 \\
\hline & & & $\mathrm{e}=0,26 \mathrm{~mm}$ & 126,3 & 120,5 & 112,1 & 108,4 & 107,0 & 106,4 \\
\hline
\end{tabular}

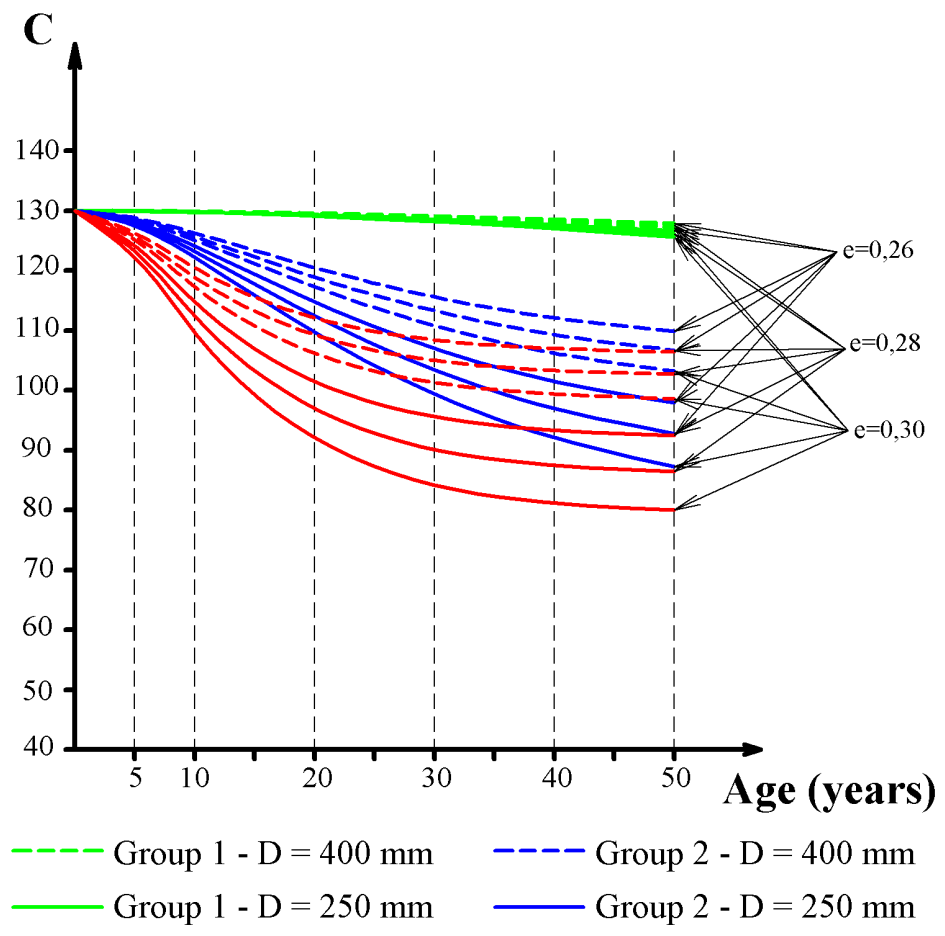

---- Group 3 - D = $400 \mathrm{~mm}$

Group $3-\mathrm{D}=250 \mathrm{~mm}$

Fig. 3. Change in the roughness coefficient $C$ of pipes with internal cement coatings from the age of their operation and the characteristics of natural waters. 
After considering figures 1,2,3, we can conclude that the pipes have a similar period of operation, the same material, but a pipe with a large diameter will have the advantage when taking into account the roughness coefficient $\mathrm{C}$. And in the hydraulic calculations of existing water supply networks with different diameters and materials of pipelines, necessary to use the value of roughness coefficient $\mathrm{C}$ taking into account the age of the pipes and the characteristics of natural waters, will allow to identify the actual pressure loss of the water supply network.

\section{References:}

[1] Panov M Ya, Levadny A S, Shcherbakov V I 2005 Modeling, optimization and control of water supply and distribution systems (Voronezh: Voronezh State University of Economics) p 489

[2] Panov M Ya, Petrov Yu F, Shcherbakov V I 2012 Models for controlling the functioning of water supply and distribution systems (Voronezh: VGASU) p 272

[3] Nikola J, Stamenic M, Radanov B, Kolendic P, Đorđevic D, Vladic L 2015 FME Transactions 43 35-39

[4] Altshul A D, Kiselev P G 1975 Hydraulics and aerodynamics (Moscow: Stroyizdat) p 332

Article sent: 05/01/2021

(C) Nguyen H.C. 